\title{
Effects of Vermicompost, Tithonia Green Manure and Urea on Quality of Swiss Chard (Beta Vulgaris L. Var. Cicla L.) in Kenya
}

\author{
N. B. Rioba ${ }^{1}$, P. A. Opala ${ }^{2}$, J. K. Bore ${ }^{3}$, S. O. Ochanda ${ }^{3} \&$ K. Sitienei ${ }^{3}$ \\ ${ }^{1}$ School of Agriculture and Biotechnology, University of Kabianga, Kenya \\ ${ }^{2}$ Department of Soil Science, Maseno University, Kenya \\ ${ }^{3}$ Tea Research Institute, Kenya Agricultural and Livestock Research Organization (KALRO), Kenya \\ Correspondence: N. B. Rioba, School of Agriculture and Biotechnology, University of Kabianga, P.O. Box \\ 2030-20200, Kericho, Kenya. E-mail: naomirioba@kabianga.ac.ke
}

Received: November 6, 2019 Accepted: January 27, 2020 Online Published: February 10, 2020

doi:10.5539/sar.v9n2p55

URL: https://doi.org/10.5539/sar.v9n2p55

\begin{abstract}
Swiss chard (Beta vulgaris L. var. cicla) is a popular vegetable because it is nutritious, robust, easy to grow. It requires regular applications of nitrogen, which causes accumulation of oxalates and nitrates within the plant. Oxalates and nitrates are known health hazards but the use of organic fertilizers have been shown to reduce their accumulation and to promote accumulation of beneficial phytochemicals. We therefore determined the effect vermicompost (VC), Tithonia diversifolia green manure (Tithonia) and urea on the quality of Swiss chard. The experiment was laid out in a Randomised Complete Block Design (RCBD) replicated three times with thirteen treatments. Leaf nutrient elements, TSS, polyohenols, Vitamin C and antioxidants were determined using standard procedures. Treatment effects were significant only for aluminum, phosphorus and calcium. The values were highest on VC $50 \mathrm{~kg} \mathrm{~N} \mathrm{ha}^{-1}$ and Urea $50 \mathrm{~kg} \mathrm{~N} h a^{-1}$, Tithonia $50 \mathrm{~kg} \mathrm{~N} \mathrm{ha}^{-1}+$ Urea $50 \mathrm{~kg} \mathrm{~N}^{-1}$, and VC 50 $\mathrm{kg} \mathrm{N} \mathrm{ha}^{-1}$, and VC $100 \mathrm{~kg} \mathrm{~N}^{-1}$ for aluminum, phosphorus and calcium, respectively. Lowest response was reported on Tithonia $50 \mathrm{~kg} \mathrm{~N}^{-1}$, control and Tithonia $50 \mathrm{~kg} \mathrm{~N} \mathrm{ha}^{-1}+$ Urea $50 \mathrm{~kg} \mathrm{~N}$ ha ${ }^{-1}$ for aluminum, phosphorus and calcium, respectively. The treatments significantly influenced the percentage of polyphenols, vitamin $\mathrm{C}$ and the antioxidant capacity while no significance was reported for total soluble solutes. The polyphenols and vitamin $\mathrm{C}$ content were highest on Tithonia $100 \mathrm{~kg} \mathrm{~N} \mathrm{ha}^{-1}$ and control, respectively. Low polyphenol and vitamin C contents were recorded on VC $50 \mathrm{~kg} \mathrm{~N}^{-1}$ and $\mathrm{VC} 100 \mathrm{~kg} \mathrm{~N}^{-1}$, respectively. A similar trend was observed for antioxidant activity since a positive correlation was observed between the polyphenols and vitamin $\mathrm{C}$ and the antioxidant activity. Tithonia green manure improves Swiss chard quality.
\end{abstract}

Keywords: Swiss chard, vermicompost, tithonia, Urea, polyphenols, vitamin C

\section{Introduction}

Swiss chard (Beta vulgaris L. var. cicla L.) a member of the family Chenopodiaceae is a biennial plant (Kretschmer, 1999). It is among the nitrate accumulating vegetables (Santamaria, 2006) because it is one of the species known to "luxury-consume" the $\mathrm{NO}_{3}{ }^{-}$ion and accumulate it to high levels in particular vacuoles to the point that such levels are often considered a health hazard for human consumption.

Swiss chard is a very important crop from the nutritional point of view (Platt, 1962). It is highly valued because it is available all year round and for its nutritional properties. It is an excellent source of vitamins $\mathrm{K}$ and $\mathrm{A}$, folic acid, dietary fibre and protein, very good source of vitamins C and E, most B vitamins and numerous minerals, especially calcium, potassium, phosphorus and manganese, as well as respectable amounts of niacin, and folic acid (Smatanova, Richter \& Hlusek, 2004; Leskovar \& Piccinni, 2005; Citak \& Sonmez, 2009). It is very low in saturated fat and cholesterol but it is naturally quite high in sodium (Mitic, Jovanovic, Dimitrijevic, Cvetkovic \& Stojanovic, 2013). The species is also concentrated in health-promoting phytonutrients such as carotenoids and flavonoids which provide powerful antioxidant protection (Bimova \& Pokluda, 2009; Fairman, 2011). Many of these vitamins and nutrients help fight various types of cancer and promote good cardiovascular health (Masarirambi, Mbokazi, Wahome \& Oseni, 2012).

On the other hand, Swiss chard is associated with antinutrients such as oxalates and nitrates (Santamaria, Elia, Serio \& Todaro, 1999) which accumulate to high levels during growth. Excessive levels of nitrates and oxalates 
have detrimental effects to human health (Santamaria et al., 1999; Ikemoto, Teraguchi \& Kogayashi, 2002; Ishiwata et al., 2002).

Some relationships between nitrates, ascorbic acid and oxalates have been established. There is an inverse relationship between ascorbic acid and nitrate content in leaf tissues (Alderfasi, Moftah \& Aljuaed, 2010; Citak \& Sonmez, 2010; Mozafar, 1993) and a slight positive correlation between nitrates and oxalates (Koh, Charoenprasert \& Mitchell, 2012; Elia, Santamaria \& Serio, 1998). This means that the nitrate and oxalates can be reduced while increasing the ascorbic acid in leafy vegetables like Swiss chard.

The relationship between nitrate accumulation and ascorbic acid suppression could be changed by using organic sources alone or in conjunction with lower amounts of $\mathrm{N}$ from inorganic sources (Alderfasi et al., 2010; Citak \& Sonmez, 2010; Mozafar, 1996; Muramoto, 1999. Vermicompost (VC) and tithonia are potential candidates of the organic sources that could be used to improve the quality of Swiss chard. Tithonia is a plant that is abundant on hedges of farms and roadsides in western Kenya and is known as an effective source of $\mathrm{N}$ for crops (Jama, Palm $\&$ Buresh, 2000).

Vermicomposting is a waste management technology that involves decomposition of organic fraction of solid waste in an ecofriendly way to a level in which it can be easily stored, handled and applied to agricultural fields without any adverse effects (Singh, Pathak, A.K. Verma, V.K., Verma \& Deka, 2011; Khwairakpam \& Bhargara, 2009; Aira, Monroy \& Dominguez, 2009). The product of vermicomposting is a finely divided, peat-like material with a low $\mathrm{C}: \mathrm{N}$ ratio, excellent structure, porosity, aeration, drainage and moisture holding capacity, and it supplies a suitable mineral balance, improves nutrient availability and could act as complex-nutrient source granules (Dominguez \& Edwards, 2011).

\section{Materials and Methods}

\subsection{Site Description}

The study was conducted between February 2016 and February, 2017 at the University of Kabianga farm in Kericho County, Kenya. The site lies at an altitude of $2163 \mathrm{M}$ above sea level $\left(0^{\circ} 49^{\prime} 0 \mathrm{~N}, 35^{\circ} 49^{\prime} 60 \mathrm{E}\right)$. The average rainfall is $900-1200 \mathrm{~mm}$ per annum distributed mainly between the months of March and December with two distinct peaks in May and October. The soils at the site are Nitisols which are acidic, moderately deep and well drained (Jaetzold \& Schmidt, 1982). The soil physical properties of the experimental site were analysed before the start of the experiments. Results were as follows; $\%$ sand $=23.07, \%$ clay $=58.20$ and $\%$ silt $=18.73$ giving the grade of the soil as clay. Selected soil chemical properties at the site were as listed in table 1, while selected chemical properties for the organic fertilizers used in the study are presented on table 2.

Table 1. Selected chemical properties of the experimental site soil

\begin{tabular}{lllllllllll}
\hline $\mathrm{pH}$ & $\mathrm{N} \mathrm{ppm}$ & $\mathrm{P} \mathrm{ppm}$ & $\mathrm{K} \mathrm{ppm}$ & $\mathrm{Ca} \mathrm{ppm}$ & $\mathrm{Mg} \mathrm{ppm}$ & Mn ppm & Zn ppm & Cu ppm & Fe ppm & Al ppm \\
\hline 4.64 & 75 & 116 & 574 & 577 & 122 & 157 & 17 & 17 & 51 & 813 \\
\hline
\end{tabular}

Table 2. Vermicompost analysis

\begin{tabular}{llllllllllllll}
\hline & $\% \mathrm{~N}$ & $\% \mathrm{P}_{2} \mathrm{O}_{5}$ & $\% \mathrm{~K}_{2} \mathrm{O}$ & $\% \mathrm{CaO}$ & $\% \mathrm{MgO}$ & $\% \mathrm{~S}$ & $\begin{array}{l}\mathrm{Ca} \\
\mathrm{ppm}\end{array}$ & $\begin{array}{l}\mathrm{Pb} \\
\mathrm{ppm}\end{array}$ & $\begin{array}{l}\mathrm{Zn} \\
\mathrm{ppm}\end{array}$ & $\begin{array}{l}\mathrm{Cu} \\
\mathrm{ppm}\end{array}$ & $\begin{array}{l}\mathrm{Fe} \\
\mathrm{ppm}\end{array}$ & $\mathrm{S} \%$ & $\mathrm{CO}-3$ \\
\hline $\begin{array}{l}\text { Vermicic } \\
\text { ompost }\end{array}$ & 4.20 & 4.02 & 0.68 & 9.42 & 0.73 & 0.48 & 43.00 & 48.00 & 110.00 & 51.00 & 2320.00 & 0.60 & 5.00 \\
\hline
\end{tabular}

\subsection{Experimental Design and Crop Management}

The experimental plots were ploughed, and harrowed. The experiment was laid out in a Randomised Complete Block Design (RCBD) replicated three times with 13 treatments as listed below:

\section{Control}

2. Vermicompost $\left(50 \mathrm{~kg} \mathrm{~N} \mathrm{ha}^{-1}\right)$

3. Vermicompost $\left(100 \mathrm{~kg} \mathrm{~N} \mathrm{ha}^{-1}\right)$

4. Tithonia $\left(50 \mathrm{~kg} \mathrm{~N} \mathrm{ha}^{-1}\right)$

5. Tithonia $\left(100 \mathrm{~kg} \mathrm{~N}^{-1}\right)$

6. Urea $\left(50 \mathrm{~kg} \mathrm{~N} \mathrm{ha}^{-1}\right)$

7. Urea $\left(100 \mathrm{~kg} \mathrm{~N} \mathrm{ha}^{-1}\right)$ 

8. Vermicompost $\left(25 \mathrm{~kg} \mathrm{~N} \mathrm{ha}^{-1}\right)+\operatorname{Urea}\left(25 \mathrm{~kg} \mathrm{~N} \mathrm{ha}^{-1}\right)$
9. Vermicompost $\left(50 \mathrm{~kg} \mathrm{~N} \mathrm{ha}^{-1}\right)+\mathrm{Urea}\left(50 \mathrm{~kg} \mathrm{~N} \mathrm{ha}^{-1}\right)$
10. Tithonia $\left(25 \mathrm{~kg} \mathrm{~N} \mathrm{ha}^{-1}\right)+\operatorname{Urea}\left(25 \mathrm{~kg} \mathrm{~N} \mathrm{ha}^{-1}\right)$
11. Tithonia $\left(50 \mathrm{~kg} \mathrm{~N} \mathrm{ha}^{-1}\right)+$ Urea $\left(50 \mathrm{~kg} \mathrm{~N} \mathrm{ha}^{-1}\right)$
12. Vermicompost $\left(100 \mathrm{~kg} \mathrm{~N} \mathrm{ha}^{-1}\right)$ without Triple Super Phosphate (TSP)
13. Tithonia $\left(100 \mathrm{~kg} \mathrm{~N} \mathrm{ha}^{-1}\right)$ without TSP

All the treatments, except 1, 12 and 13, had the recommended amounts of $\mathrm{P}\left(30 \mathrm{~kg} \mathrm{ha}^{-1}\right)$ applied.

Vermicompost was obtained from composting waste tea leaves and poultry manure using Eisenia foetida [which is the most commonly used species (Haimi \& Huhta, 1990) and is raised in Kenya by several flower farms from which the worms were sourced. A bed was prepared with a plastic sheet bottom and $30 \mathrm{~cm}$ wooden walls. A layer of $15 \mathrm{~cm}$ waste tea leaves were placed on the bed and poultry manure was added at the weight ratio of 3:1 (i.e waste tea leaves: poultry manure). The mixture was then moistened before addition of the worms by placing small handfuls of material rich in the worms into 'holes' of about $50 \mathrm{~cm}$ apart. The bed was then covered using a dark polyethene plastic and allowed to mature for 60 days during which time the materials were watered and turned once every week for the first two weeks and fortnightly thereafter until maturity. Occasionally, additional poultry manure was buried at different parts of the bed as extra food for the worms. There were earthworms harvested from the mature vermicompost to allow for the use of the vermicompost. The vermicompost was air dried for seven days before field application. On the other hand, Tithonia was sourced from neighbouring farms and roadside. The green leaf biomass of Tithonia has been shown to be high in nutrients averaging about $3.5 \%$ $\mathrm{N}, 0.37 \% \mathrm{P}$ and $4.1 \% \mathrm{~K}$ on a dry matter basis (Jama et al., 2000). The vegetative parts (tender shoots and leaves) were chopped into small pieces and used as green manure.

The size of experimental plot was $2.1 \mathrm{~m} \times 2.1 \mathrm{~m}$. Plant establishment was done using nursery grown one month-old seedlings of Swiss chard; variety 'Giant Fordhork' at a spacing of $30 \mathrm{~cm}$ x $15 \mathrm{~cm}$. The VC, Tithonia and half the amount urea were worked into the soil just before transplanting was done with the remaining half of the urea applied four weeks after transplanting (for the treatments where urea was used as a sole source of $\mathrm{N}$ ). Where Urea was to be used in combination with the organic source of $\mathrm{N}$, all the urea was applied as a top-dress. All the TSP was applied at planting. All recommended cultural practices were adopted uniformly according to standard crop requirements.

Ten inner rows plants/plot were tagged and used for data collection. Data on nutrient elements, polyphenols, total soluble solutes, vitamin $\mathrm{C}$ and antioxidant activity was taken based on the tagged plants.

\subsection{Determination of Leaf Nutrient Elements}

Leaf samples were oven-dried at $65{ }^{\circ} \mathrm{C}$ for 3 days and ground into powder, they were prepared and analysed for Calcium, Magnesium, Copper, Zinc, Iron, Manganese using atomic absorption spectrophotometry on a dry weight (DW) bases according to Zarei (1995). Phosphorus (P) was determined using Olsen method and Potassium (K) using flame photometer (Humphries, 1956).

\subsection{Determination of Total Polyphenols}

Extraction of total polyphenols was done according to the procedure by Karori, Wachira, Wanyoko \& Ngure (2007). Ground Swiss chard samples $(0.2 \mathrm{~g})$ were weighed into graduated extraction tubes and $5 \mathrm{ml}$ of $70 \%$ hot methanol/water v/v (MeOH) added, stoppered and mixed under vortex. Incubation followed at $70{ }^{\circ} \mathrm{C}$ for 10 minutes (water bath) with vortexing at 0,5 , and 10 minutes. Cooling to rtp and then centrifuging at $3000 \mathrm{rpm}$ for 10 minutes was done. A second extraction was performed and $10 \mathrm{ml}$ with cold methanol/water $\mathrm{v} / \mathrm{v}(\mathrm{MeOH})$ at $70 \%$. Extracted samples were complexed using $75 \%$ sodium carbonate and 10\% Folin-ciocalteu reagent (Phenol) and absorbance read at $765 \mathrm{~nm}$. The total polyphenol content was expressed as a percentage by mass on a sample dry matter (Karori et al., 2007)

\subsection{Determination of Vitamin $C$}

Vitamin C (ascorbic acid) was extracted by blending $20 \mathrm{~g}$ of chopped fruits with $100 \mathrm{~mL}$ of $0.4 \%$ (w/v) oxalic acid solution and quantified using the potassium ferriccyanide method (Hashmi, 1973).

\subsection{Determination of Antioxidant Activity}

The total reducing power of Swiss chard sample was determined according to the Ferric Reducing Antioxidant Power (FRAP) method as described by (Yildirim, Mavi, Kara, 2001). A $2.5 \mathrm{~mL}$ volume of the Swiss chard sample was mixed with $2.5 \mathrm{~mL}$ phosphate buffer solution $(0.2 \mathrm{M}, \mathrm{pH}=6.6)$ and $2.5 \mathrm{~mL}$ of $1 \%$ potassium 
ferriccyanide $\left[\mathrm{K}_{3} \mathrm{Fe}(\mathrm{CN})_{6}\right]$ in tubes. The mixture was placed in a water bath of $50{ }^{\circ} \mathrm{C}$, for 20 minutes. A volume of $2.5 \mathrm{~mL}$ of $10 \%$ trichloroacetic acid (TCA) was added to the mixture and mixed thoroughly. A volume of 2.5 of this mixture was then mixed with $2.5 \mathrm{~mL}$ distilled water and $0.5 \mathrm{~mL} \mathrm{FeCl}_{3}$ of $0.1 \%$ solution and allowed to stand for 10 minutes. The absorbance of the mixture was measured at 700nm using a UV-VIS spectrophotometer; the higher the absorbency of the reaction mixture, the greater the reducing power. Ascorbic acid was used as a positive control for this assay. All procedures were performed in triplicate.

\subsection{Data Analysis}

The data was subjected to the Analysis of Variance (ANOVA) using Mstat C computer software package (Russel, 1995). The Least Significant Difference (LSD) procedure was then used to separate differences among the treatment means at $\mathrm{p}<0.05$.

\section{Results and Discussion}

Nutritional quality of Swiss chard was characterized by total soluble solids (TSS), ascorbic acid, antioxidant capacity, total polyphenol content, total soluble solutes and minerals (nitrogen, phosphorus, potassium, calcium, magnesium, manganese aluminum, copper, iron and zinc).

\subsection{Mineral Elements}

Table 3. Effects of Vermicompost, Tithonia and Urea on Leaf Tissue Analysis (Season 1)

\begin{tabular}{|c|c|c|c|c|c|c|c|c|c|c|}
\hline $\begin{array}{l}\text { Treatments/ } \\
\text { nutrients }\end{array}$ & $\% \mathrm{Al}$ & $\% \mathrm{Ca}$ & $\% \mathrm{~K}$ & $\% \mathrm{Mg}$ & $\% \mathrm{Mn}$ & $\% \mathrm{~N}$ & $\% \mathrm{P}$ & $\begin{array}{l}\mathrm{Cu} \\
(\mathrm{ppm})\end{array}$ & $\begin{array}{l}\mathrm{Fe} \\
(\mathrm{ppm})\end{array}$ & $\mathrm{Zn}(\mathrm{ppm})$ \\
\hline 1. Control & 0.48 & 1.36 & 4.47 & 0.92 & 0.07 & 2.75 & 0.44 & 29.33 & 147.30 & 59.30 \\
\hline 2. VC50 kg N ha ${ }^{-1}$ & 0.41 & 0.90 & 3.42 & 0.56 & 0.07 & 2.42 & 0.48 & 29.33 & 112.36 & 59.00 \\
\hline 3. VC100 kg N ha ${ }^{-1}$ & 0.40 & 1.03 & 3.94 & 0.66 & 0.07 & 2.71 & 0.46 & 29.33 & 135.70 & 70.30 \\
\hline 4. Tithonia $50 \mathrm{~kg} \mathrm{~N} \mathrm{ha}^{-1}$ & 0.30 & 0.58 & 3.13 & 0.46 & 0.04 & 3.88 & 0.54 & 29.00 & 114.7 & 63.00 \\
\hline 5. Tithonia $100 \mathrm{~kg} \mathrm{~N} \mathrm{ha}^{-1}$ & 0.31 & 0.85 & 4.13 & 0.79 & 0.34 & 2.66 & 0.43 & 29.33 & 84.30 & 57.70 \\
\hline 6. Urea $50 \mathrm{~kg} \mathrm{~N} \mathrm{ha}^{-1}$ & 0.46 & 1.25 & 4.61 & 0.80 & 0.07 & 3.59 & 0.53 & 29.33 & 187.30 & 42.10 \\
\hline 7. Urea $100 \mathrm{~kg} \mathrm{~N}^{-1}$ & 0.36 & 1.03 & 3.58 & 0.74 & 0.07 & 2.93 & 0.51 & 29.67 & 126.00 & 58.30 \\
\hline 8. VC25 kg N ha ${ }^{-1}+$ Urea $25 \mathrm{~kg} \mathrm{~N}^{-1}$ & 0.41 & 0.97 & 4.61 & 0.82 & 0.07 & 4.10 & 0.60 & 30.33 & 145.30 & 61.30 \\
\hline 9. VC50 kg N ha ${ }^{-1}+$ Urea $50 \mathrm{~kg} \mathrm{~N} \mathrm{ha}^{-1}$ & 0.55 & 1.03 & 3.92 & 0.76 & 0.07 & 2.54 & 0.47 & 29.67 & 149.30 & 63.00 \\
\hline 10. Tithonia $25 \mathrm{~kg} \mathrm{~N} \mathrm{ha}^{-1}+$ Urea $25 \mathrm{~kg} \mathrm{~N} \mathrm{ha}^{-1}$ & 0.45 & 1.11 & 4.57 & 0.71 & 0.08 & 2.74 & 0.45 & 30.00 & 174.00 & 62.70 \\
\hline 11. Tithonia $50 \mathrm{~kg} \mathrm{~N} \mathrm{ha}^{-1}+$ Urea $50 \mathrm{~kg} \mathrm{~N} \mathrm{ha}^{-1}$ & 0.41 & 0.86 & 3.82 & 0.65 & 0.06 & 2.91 & 0.52 & 29.67 & 126.70 & 66.00 \\
\hline 12. VC100 kg N ha-1 & 0.40 & 0.95 & 3.51 & 0.65 & 0.07 & 2.56 & 0.50 & 32.33 & 98.00 & 64.00 \\
\hline 13. Tithonia $100 \mathrm{~kg} \mathrm{~N} \mathrm{ha}^{-1}$ & 0.35 & 1.10 & 4.13 & 0.76 & 0.07 & 2.83 & 0.45 & 31.33 & 88.70 & 65.70 \\
\hline Significance & $\mathrm{S}$ & NS & NS & NS & NS & NS & NS & NS & NS & NS \\
\hline LSD & 0.14 & 0.59 & 1.19 & 0.35 & 0.22 & 1.28 & 0.12 & 2.11 & 67.02 & 19.32 \\
\hline
\end{tabular}

Table 4. Effects of Vermicompost, Tithonia and Urea on Leaf Tissue Analysis (Season 2)

\begin{tabular}{|c|c|c|c|c|c|c|c|c|c|c|}
\hline Treatments/ nutrients & $\% \mathrm{Al}$ & $\% \mathrm{Ca}$ & $\% \mathrm{~K}$ & $\% \mathrm{Mg}$ & $\% \mathrm{Mn}$ & $\% \mathrm{~N}$ & $\% \mathrm{P}$ & $\mathrm{Cu}(\mathrm{ppm})$ & $\mathrm{Fe}(\mathrm{ppm})$ & $\mathrm{Zn}(\mathrm{ppm})$ \\
\hline 1. Control & 0.27 & 1.36 & 4.51 & 0.823 & 0.072 & 2.33 & 0.41 & 29.33 & 95.00 & 66.00 \\
\hline 2. VC50 kg N ha ${ }^{-1}$ & 0.22 & 1.05 & 4.81 & 0.80 & 0.07 & 3.35 & 0.53 & 28.33 & 80.70 & 65.00 \\
\hline 3. VC100 kg N ha-1 & 0.21 & 1.16 & 4.52 & 0.85 & 0.08 & 2.74 & 0.49 & 30.00 & 90.30 & 69.70 \\
\hline 4. Tithonia $50 \mathrm{~kg} \mathrm{~N} \mathrm{ha}^{-1}$ & 0.21 & 1.19 & 4.72 & 0.88 & 0.08 & 2.74 & 0.47 & 29.00 & 91.70 & 66.30 \\
\hline 5. Tithonia $100 \mathrm{~kg} \mathrm{~N} \mathrm{ha}^{-1}$ & 0.21 & 1.14 & 4.38 & 0.84 & 0.08 & 2.77 & 0.46 & 31.00 & 87.30 & 67.30 \\
\hline 6. Urea $50 \mathrm{~kg} \mathrm{~N}^{-1}$ & 0.21 & 1.23 & 4.73 & 0.89 & 0.09 & 2.88 & 0.48 & 29.00 & 93.70 & 69.70 \\
\hline 7. Urea $100 \mathrm{~kg} \mathrm{~N} \mathrm{ha}^{-1}$ & 0.20 & 1.34 & 4.39 & 0.92 & 0.09 & 3.05 & 0.48 & 30.33 & 81.00 & 68.70 \\
\hline 8. VC $25 \mathrm{~kg} \mathrm{~N}^{-1}+$ Urea $25 \mathrm{~kg} \mathrm{~N}^{-1}$ & 0.21 & 1.32 & 4.68 & 0.75 & 0.09 & 2.57 & 0.45 & 28.33 & 85.70 & 67.30 \\
\hline 9. VC $50 \mathrm{~kg} \mathrm{~N} \mathrm{ha}^{-1}+$ Urea $50 \mathrm{~kg} \mathrm{~N}^{-1}$ & 0.21 & 1.11 & 4.27 & 0.78 & 0.07 & 2.60 & 0.45 & 28.67 & 72.70 & 68.30 \\
\hline 10. Tithonia $25 \mathrm{~kg} \mathrm{~N} \mathrm{ha}^{-1}+$ & 0.20 & 1.09 & 4.89 & 0.90 & 0.09 & 2.52 & 0.47 & 29.33 & 94.30 & 66.70 \\
\hline \multicolumn{11}{|l|}{ Urea $25 \mathrm{~kg} \mathrm{~N} \mathrm{ha}^{-1}$} \\
\hline 11. Tithonia $50 \mathrm{~kg} \mathrm{~N} \mathrm{ha}^{-1}+$ & 0.22 & 1.05 & 4.45 & 0.89 & 0.07 & 3.09 & 0.53 & 29.67 & 91.00 & 68.30 \\
\hline \multicolumn{11}{|l|}{ Urea $50 \mathrm{~kg} \mathrm{~N} \mathrm{ha}^{-1}$} \\
\hline 12. VC $100 \mathrm{~kg} \mathrm{~N} \mathrm{ha}^{-1}$ & 0.21 & 1.69 & 4.72 & 0.94 & 0.09 & 2.58 & 0.43 & 31.33 & 75.70 & 71.30 \\
\hline 13. Tithonia $100 \mathrm{~kg} \mathrm{~N}^{-1}$ & 0.23 & 1.50 & 5.60 & 1.00 & 0.09 & 2.65 & 0.42 & 30.33 & 93.00 & 67.70 \\
\hline Significance & NS & $\mathrm{S}$ & NS & NS & NS & NS & S & NS & NS & NS \\
\hline LSD & 0.08 & 0.18 & 1.21 & 0.27 & 0.02 & 0.71 & 0.07 & 2.61 & 26.04 & 15.70 \\
\hline
\end{tabular}


For Aluminum, (Season 1) the highest levels $(0.55 \%)$ were recorded in plants grown on soil that received VC at $50 \mathrm{~kg} \mathrm{~N} \mathrm{ha}^{-1}$ and Urea at $50 \mathrm{~kg} \mathrm{~N} \mathrm{ha}^{-1}$. The least (0.30) was recorded on Tithonia at $50 \mathrm{~kg} \mathrm{~N}^{-1}$ with TSP application (Table 3).

Leaf tissue nitrogen showed inconsistent and non-significant response to treatments in both seasons (Tables 3 \& 4). During the first season, the $\mathrm{N}$ content was highest (4.10\%) on VC $25 \mathrm{~kg} \mathrm{~N} \mathrm{ha}^{-1}+$ Urea $25 \mathrm{~kg} \mathrm{~N}^{-1}$ making a total of $50 \mathrm{~kg} \mathrm{~N} h a^{-1}$ and the least $(2.42 \%)$ on VC $50 \mathrm{~kg} \mathrm{~N} \mathrm{ha}^{-1}$. In the second season, the highest $\mathrm{N}$ content was recorded on $\mathrm{VC} 50 \mathrm{~kg} \mathrm{~N} \mathrm{ha}^{-1}(2.42 \%)$ was recorded on $\mathrm{VC} 50 \mathrm{~kg} \mathrm{~N} \mathrm{ha}^{-1}$ and the least $(2.33 \%)$ on the control where no form of fertilizer was applied. It is worth noting that though not significantly different, leaf $\mathrm{N}$ content was highest in vermicompost alone or combined with urea at the lowest rate of application $\left(50 \mathrm{~kg} \mathrm{~N} \mathrm{ha}^{-1}\right)$. This is contrary to findings by Hernandez et al. (2010) who observed that leaf $\mathrm{N}$ concentration in inorganic fertilizer treated plants was higher than organically treated plants. This is so because organic fertilizers are slow release $\mathrm{N}$ fertilizers and only mineralizes a fraction of total $\mathrm{N}$ estimated at $2 \%$ in a crop cycle (Castellanos, Uralle-Bueno \& Aguilar-Santelises, 2000; Sikora \& Szmidt, 2005) while urea is characterized as an N-rich source (Arroyo, Rojas \& Rosales, 2003) with high solubility of N (Capulin, Nunez, Etchevers \& Baca, 2001). All in all, the fertilizer treatments afforded sufficient levels of $\mathrm{N}$ (2.33-4.10\%) with reference to sufficiency levels of 2.50-4.50\% as given by Munson (1998).

Phosphorus content in Swiss chard leaves was significantly influenced in season 2 but not in season 1 (Tables 3 \& 4). Two treatments yielded the highest content $(0.5267 \%)$ of tissue phosphorus; Tithonia at $50 \mathrm{~kg} \mathrm{~N} \mathrm{ha}{ }^{-1}+$ Urea at $50 \mathrm{~kg} \mathrm{~N} \mathrm{ha}^{-1}$ and $\mathrm{VC}$ at $\mathrm{kg} \mathrm{N} \mathrm{ha}^{-1}$ during season 2 . The lowest amounts $(0.41 \%)$ were observed on the control where no form of fertilizer was applied. These findings partly agree with those of Hernandez et al. (2010) who report no significant differences in P content in spinach leaf tissue. The levels of $\mathrm{P}(0.41-0.60 \%)$ in the current study attained the sufficiency level for this element according to Munson, 1998 who provided a range of $0.20-0.75 \%$. It has been reported that green biomass of Tithonia is rapid and that Tithonia can supply plant available $\mathrm{P}$ at least as effectively as an equivalent amount of $\mathrm{P}$ from soluble fertilizer. Nziguheba, Palm, Buresha \& Smithson (1998) reported that labile inorganic soil $\mathrm{P}$ as determined by extraction with anion exchange resin, was higher at 2 weeks after incorporation of $15 \mathrm{~kg} \mathrm{P}^{-\mathrm{ha}^{-1}}$ as Tithonia $\left(8.1 \mathrm{mg} \mathrm{Pkg}^{-1}\right)$ than as TSP (3.6 mg Pkg$\left.{ }^{-1}\right)$ on acid soil. This could explain why it was possible to register a significantly higher $\mathrm{P}$ content in leaf tissues of Swiss chard grown on soil fertilized with Tithonia at $50 \mathrm{~kg} \mathrm{~N} \mathrm{ha}^{-1}$ in addition to Urea at the same rate.

The response for potassium $(\mathrm{K})$ was not significant in all the treatments across the seasons (Tables $3 \& 4$ ). However, $\mathrm{K}$ leaf tissue concentrations were highest $(4.61 \%)$ on Urea $50 \mathrm{~kg} \mathrm{~N} \mathrm{ha}^{-1}$ as well as on VC $25 \mathrm{~kg} \mathrm{~N} \mathrm{ha}^{-1}$ + Urea $25 \mathrm{~kg} \mathrm{~N} \mathrm{ha}^{-1}$ and lowest (3.13) on Urea $25 \mathrm{~kg} \mathrm{~N}$ ha $^{-1}$ during the first season. In season 2, the highest (5.60\%) was recorded on $100 \mathrm{~kg} \mathrm{~N} \mathrm{ha}^{-1}$ applied as Tithonia with no other fertilizer and the least on $100 \mathrm{~kg} \mathrm{~N} \mathrm{ha}^{-1}$ applied as VC without any fertilizer. This is in agreement with Hernandez et al. (2010) who showed that leaf K content in plants treated with urea was higher than that of vermicompost though the differences were not significant. All the treatments presented $\mathrm{K}$ at sufficient levels (3.13-5.6\%) based on sufficiency amounts (1.50-5.50 \%) given by Munson (1998). Despite the highest level exceeding the limits by Munson (1998), K content is not high enough to cause toxicity set at $>6.00 \%$ (Munson, 1998). This findings emphasize the importance of urea, vermicompost and Tithonia as potential sources of $\mathrm{K}$ for Swiss chard production.

Calcium accumulation in the Swiss chard leaves was significantly influenced by the treatments in Season 2 but not in Season 1 (Tables $3 \&$ 4). During season 1, the highest percentage $(1.36 \%)$ was recorded on plants that received $0 \mathrm{~kg} \mathrm{~N} \mathrm{ha}^{-1}$ and the least $(0.58 \%)$ on plants receiving $50 \mathrm{~kg} \mathrm{~N} \mathrm{ha}^{-1}$ applied as green manure of Tithonia. In the second season, greatest $(1.69 \%)$ calcium accumulated on $100 \mathrm{~kg} \mathrm{~N} \mathrm{ha}^{-1}$ supplied by vermicompost without any fertilizer application and the least $(1.05 \%)$ on plots that received $50 \mathrm{~kg} \mathrm{~N}^{-1}$ from urea and $50 \mathrm{~kg}$ $\mathrm{N}$ ha ${ }^{-1}$ from Tithonia. This means that sole organic fertilizer supplied more calcium to the plant than with combined sources i.e organic and inorganic fertilizer used in combination. The amount (0.58- $1.68 \%)$ of calcium across the treatments reached the sufficiency levels described by Munson (1998) as 1.00-4.00\%.

In season 1, magnesium content in the leaves was highest $(0.92 \%)$ on the control that received no fertilizer application and the least $(0.46 \%)$ was on Tithonia at $50 \mathrm{~kg} \mathrm{~N} \mathrm{ha}^{-1}$ (Table 3). In season 2 (Table 4), the highest amounts $(1.00 \%)$ was recorded on Tithonia at $100 \mathrm{~kg} \mathrm{~N}^{-1}$ and least $(0.75 \%)$ on VC $25 \mathrm{~kg} \mathrm{~N}^{-1}+$ Urea $25 \mathrm{~kg}$ $\mathrm{N} \mathrm{ha}^{-1}$. However, magnesium content was not significantly influenced by the treatments in both seasons. The amount of magnesium (0.46-1.00\%) across the treatments fitted within the sufficiency levels $(0.25-1.00 \%)$ and below the toxicity levels of $>1.50 \%$ (Munson, 1998).

During the first season (Table 3), Mn concentration was highest $(0.34 \%)$ on Tithonia at $100 \mathrm{~kg} \mathrm{~N} \mathrm{ha}^{-1}$ and lowest $(0.04 \%)$ on Tithonia at $50 \mathrm{~kg} \mathrm{~N} \mathrm{ha}^{-1}$. In season 2 (Table 4), the highest $(0.09 \%)$ was recorded on Tithonia 
applied at the rate of $100 \mathrm{~kg} \mathrm{~N} h a^{-1}$ and the least on VC $50 \mathrm{~kg} \mathrm{~N} h a^{-1}+$ Urea $50 \mathrm{~kg} \mathrm{~N} \mathrm{ha}^{-1}$.

Copper leaf content was highest (32.33 ppm) on VC $100 \mathrm{~kg} \mathrm{~N} \mathrm{ha}^{-1}$ and least (29.00 ppm) on Tithonia at the rate of $50 \mathrm{~kg} \mathrm{~N}^{-1}$ while in the second season, the highest $(31.33 \mathrm{ppm})$ was recorded on VC $100 \mathrm{~kg} \mathrm{~N}^{-1}$ without any inorganic fertilizer application and the least (29.00 ppm) on VC $50 \mathrm{~kg} \mathrm{~N} \mathrm{ha}^{-1}$ and VC $25 \mathrm{~kg} \mathrm{~N}^{-1}+$ Urea 25 $\mathrm{kg} \mathrm{N} \mathrm{ha}^{-1}$. The treatment effects were however not significantly different in both seasons (Tables $3 \& 4$ ).

The response of leaf iron content was not significantly influenced by the treatments in both seasons (Tables $3 \&$ 4). However, during the first season, the highest Fe content (187.30 ppm) was recorded on Urea $50 \mathrm{~kg} \mathrm{~N} \mathrm{ha}^{-1}$ and the least $(88.70 \mathrm{ppm})$ on Tithonia at $\mathrm{kg} \mathrm{N} \mathrm{ha}^{-1}$ without any inorganic fertilizer application. In the second season,

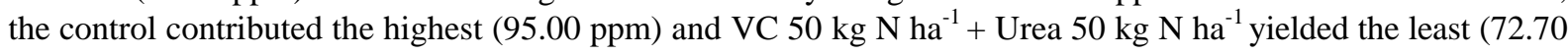
ppm).

Zinc concentration in season 1 (Table 3) was highest (70.30 ppm) on VC $100 \mathrm{~kg} \mathrm{~N}$ ha $^{-1}$ and least on Urea $50 \mathrm{~kg}$ $\mathrm{N} \mathrm{ha}^{-1}$. During the second season (Table 4), it was highest (71.30 ppm) on VC $100 \mathrm{~kg} \mathrm{~N} \mathrm{ha}^{-1}$ without any inorganic fertilizer and least (65.00 ppm) on VC $50 \mathrm{~kg} \mathrm{~N} \mathrm{ha}^{-1}$ with an application of TSP.

Table 5. Effects of Vermicompost, Tithonia and Urea on Selected Quality Parameters

\begin{tabular}{|c|c|c|c|c|}
\hline Treatments & Polyphenols $(\%)$ & Total Soluble Solutes $\left({ }^{\circ}\right.$ Brix $)$ & Vitamin C $(\%)$ & Antioxidant $(\%)$ \\
\hline 1. Control & 1.34 & 0.035 & 32.46 & 12.14 \\
\hline 2. VC $50 \mathrm{~kg} \mathrm{~N} \mathrm{ha}^{-1}$ & 0.47 & 0.05 & 15.68 & 6.75 \\
\hline 3. VC $100 \mathrm{~kg} \mathrm{~N} \mathrm{ha}^{-1}$ & 0.64 & 0.03 & 21.36 & 8.70 \\
\hline 4. Tithonia $50 \mathrm{~kg} \mathrm{~N} \mathrm{ha}^{-1}$ & 0.95 & 0.03 & 22.46 & 10.12 \\
\hline 5. Tithonia $\mathrm{kg} \mathrm{N} \mathrm{ha}^{-1}$ & 1.197 & 0.04 & 23.06 & 10.28 \\
\hline 6. Urea $50 \mathrm{~kg} \mathrm{~N} \mathrm{ha}^{-1}$ & 0.82 & 0.04 & 14.56 & 4.87 \\
\hline 7. Urea $100 \mathrm{~kg} \mathrm{~N} \mathrm{ha}^{-1}$ & 0.90 & 0.03 & 21.17 & 10.38 \\
\hline 8. VC $25 \mathrm{~kg} \mathrm{~N}^{-1}+$ Urea $25 \mathrm{~kg} \mathrm{~N}^{-1}$ & 0.98 & 0.04 & 26.51 & 10.11 \\
\hline 9. VC $50 \mathrm{~kg} \mathrm{~N} \mathrm{ha}^{-1}+$ Urea $50 \mathrm{~kg} \mathrm{~N} \mathrm{ha}^{-1}$ & 1.23 & 0.03 & 25.73 & 9.84 \\
\hline 10. Tithonia $\mathrm{kg} \mathrm{N} \mathrm{ha}^{-1}+$ Urea $25 \mathrm{~kg} \mathrm{~N} \mathrm{ha}^{-1}$ & 1.13 & 0.04 & 21.85 & 10.74 \\
\hline 11. Tithonia $50 \mathrm{~kg} \mathrm{~N} \mathrm{ha}^{-1}+$ Urea $50 \mathrm{~kg} \mathrm{~N}^{-1}$ & 0.70 & 0.04 & 15.79 & 6.13 \\
\hline 12. VC $100 \mathrm{~kg} \mathrm{~N} \mathrm{ha}^{-1}$ & 0.84 & 0.03 & 13.88 & 6.72 \\
\hline 13. Tithonia $100 \mathrm{~kg} \mathrm{~N} \mathrm{ha}^{-1}$ & 1.64 & 0.03 & 31.58 & 11.58 \\
\hline Significance & $\mathrm{S}$ & NS & $\mathrm{S}$ & $\mathrm{S}$ \\
\hline LSD VALUE & 0.61 & 0.02 & 1.50 & 3.41 \\
\hline
\end{tabular}

\subsection{Polyphenols}

The percent polyphenols were significantly influenced by the fertilizer treatments (Table 5). The percent polyphenols in the leaves of Swiss chard were highest $(1.64 \%)$ on plants that were fertilized with Tithonia at $100 \mathrm{~kg} \mathrm{~N} \mathrm{ha}^{-1}$ without any inorganic fertilizer. This treatment was not significantly different with the amount of polyphenols recorded on plants that received no fertilizer application (control). The lowest amounts of polyphenols $(0.47 \%)$ on vermicompost at $50 \mathrm{~kg} \mathrm{~N} \mathrm{ha}^{-1}$. These findings are similar to those reported by Lesser and Treutter (2005) who indicated that lower levels of phenolic and flavonoid compounds in plants grown under high $\mathrm{N}$ supply. In Contrast, other researchers have reported that higher phenolic contents are observed when nutrient availability was limited at the lowest applied nitrogen treatment (Ibrahim, Jaafar, Rahmat \& Rahman, 2011; Munene, Changamu, Korir \& Gweyi-Onyango, 2017; Salahas, Papasavvas, Giannakopoulos, Tselios \& Savvas, 2011; Argyropoulou, Salahas, Hela \& Papasavvas, 2015). This could be an indication that biosynthesis of secondary plant metabolites is stimulated by N deficiency as reported by Scheible et al. (2004). To account for the findings in the current research, the results of high percentage of polyphenols on the plants fertilized with Tithonia without application of any inorganic fertilizer could be as a result of the fast decomposition of Tithonia leaf biomass suggesting a more rapid release of $\mathrm{N}$ than uptake of $\mathrm{N}$ by the plants leading to a low crop recovery of the $\mathrm{N}$ in the Tithonia as was observed by (Jama et al., 2000) and hence the high amounts of polyphenols. Furthermore, Tithonia has been reported to have a high $\mathrm{N}$ content but it is too low in phosphorus to meet the crop P demand (Palm, Gachengo, Delve, Cadisch \& Giller, 2001) resulting in a P- nutrient stress that could have caused an increase in the synthesis and accumulation of the polyphenols in the Swiss chard plants in this treatment. Vermicompost fertilization has been reported not exerting any significant effects in the expression of bioactive compounds (Yusof, Ramasamy, Mahmoud \& Yaacob, 2018) as was observed in the current study. Coria-Cayupan, De Pinto and Nazareno, (2009); Pant, Radovich, Hue, Talcott \& Krenek (2009) and Lujan-Hidalgo et al. (2015) reported low secondary metabolites with application of vermicompost. This 
observation can be attributed to the fact that vermicompost provides nutrients to the plants in readily available forms such as nitrogen and enhances plant nutrient uptake (Adhikary, 2012). This is evident in the current study as the major nutrients (N. P and K) were highest in leaves of Swiss chard fertilized with VC at various levels (sole or in combination with inorganic fertilizer) (Tables 3 and 4).

\subsection{Total Soluble Solutes}

The greatest TSS (0.05) were recorded on VC $50 \mathrm{~kg} \mathrm{~N} \mathrm{ha}^{-1}$ and least on urea at $100 \mathrm{~kg} \mathrm{~N} \mathrm{ha}^{-1}$. However, the differences were not significantly different among the treatments. Different observations were made by Fatondji, Pasternak \& Woltering, 2008; Massri \& Labban, 2014; Vazquez et al., 2018). They reported that organic fertilizers are not related to total soluble solids.

\subsection{Vitamin $C$}

Vitamin $\mathrm{C}$ is one of the most important components in plants and animals with important antioxidant and metabolic functions in the form of vitamin $\mathrm{C}$ but humans have lost the capacity to synthesize it (Nishikimi, Fukuyama, Minoshima, Shimizu \& Yagi, 1994) and hence it must be provided from the diet (Hillstrom, Yacapin-Ammons \& Lynch, 2003).

The amount of vitamin $\mathrm{C}$ in Swiss chard was significantly affected by the treatments. More vitamin C accumulated in the plants grown with no form of fertilizer and least on VC $100 \mathrm{~kg} \mathrm{~N} \mathrm{ha}^{-1}$ without any other inorganic fertilizer application. However, Tithonia organic fertilizer yielded almost the same as the control and much more than that accumulated on plants grown on VC $100 \mathrm{~kg} \mathrm{~N} \mathrm{ha}^{-1}$ without any other fertilizer.

There are varied observations from literature regarding the effect of $\mathrm{N}$ on the accumulation of vitamin $\mathrm{C}$ in plants. Some researchers have reported that increasing doses of nitrogen depressed vitamin C content (Dzida, Jarosz \& Michalojc, 2012; Rajasree \& Pillai, 2012; Stefanelli, Goodwin \& Jones, 2010; Welch, 2016). Contrary, Miceli \& Miceli (2014); Hassan, Mijin, Yuseff, Ding \& Wahab (2012) and Ivanovic. (2018) reported that increasing the rate of $\mathrm{N}$ fertilization increased the content of vitamin $\mathrm{C}$. This difference could be explained by the differences in plant species, climatic conditions, fertilization and other agricultural practices used (Ivanovic et al., 2018).

The current study clearly indicates that different types of fertilizer have different effects on vitamin C. Vermicompost at its highest rate of application without inorganic fertilizer yielded the least vitamin $\mathrm{C}$ which could be linked to the fact that vermicomposts have been shown to have low levels of ammonium- $\mathrm{N}$ and higher Nitrate-N (Edwards \& Burrows, 1988; Arancon \& Edwards, 2004; Arancon, Edwards, Bierman, Welch \& Metzger, 2004) which could have been the reason why VC yielded low content of vitamin C since plants supplied with ammonium- $\mathrm{N}$ fertilizer contain less ascorbic acid than the same plants supplied with nitrate- $\mathrm{N}$ (Mozafar, 1993).

\subsection{Antioxidant Activity}

The antioxidant activity of Swiss chard was significantly influenced by the treatments. The highest activity $(12.14 \%)$ was recorded on the control and the least $(4.87 \%)$ on urea at $50 \mathrm{~kg} \mathrm{~N}^{-1}$. Antioxidants are compounds that can delay or inhibit the oxidation of lipids or other molecules by inhibiting the initiation or propagation of oxidative chain reactions (Velioglu, Mazza, Gao \& Oomah, 1998). The antioxidant activity of plant parts is mainly contributed by the constituent phenolic and flavonoid compounds (Soobrattee, Neergheen, Luximon-Ramma, Aruoma \& Bahorun, 2005; Panche, Diwan \& Chandra, 2016). Nitrogen fertilization has been shown to affect antioxidant activity in basil treated with the highest applied $\mathrm{N}$ level exhibiting lower antioxidant activity (Nguyen \& Niemeyer, 2008).

\subsection{Relationship between Antioxidant Activity and TSS, Vitamin C and Polyphenols}

Polyphenols positively correlated with Vitamin $\mathrm{C}$ and antioxidant activity while total soluble solids negatively correlated with the vitamin $\mathrm{C}$, polyphenols and antioxidant activity in line with the carbon/Nutrient balance theory and growth rate and growth-differentiation balance hypothesis, indicating that the allocation of plant metabolism toward higher carbon-containing components (ascorbic acid and polyphenols) and lower nitrogen-containing compounds (TSS). Total phenols are effective antioxidants or free radical scavengers (Ogembo, 2015; Okello, 2015) in leafy vegetables. Similarly, Vitamin C has been known to have marked nucleophilic properties and the ability to capture and deactivate free radicals or reactive oxygen species produced by metals (Jiraungkoorskul \& Sahaphong, 2007). This is a clear indication of the positive relationship between polyphenols and the antioxidant activity of Swiss chard. 
Table 6. Coefficients of Correlation (R) Between Antioxidant Activity and TSS, Vitamin C and Polyphenols

\begin{tabular}{ll}
\hline Quality parameters & R values \\
\hline Total Soluble Solutes $\left({ }^{\circ}\right.$ Brix $)$ & -0.474 \\
Vitamin C $(\%)$ & +0.898 \\
Polyphenols $(\%)$ & +0.748 \\
\hline
\end{tabular}

\section{Conclusion \& Recommendations}

Treatment effects were significant only for aluminum, phosphorus and calcium. The values were highest on VC $50 \mathrm{~kg} \mathrm{~N} \mathrm{ha}^{-1}$ and Urea $50 \mathrm{~kg} \mathrm{~N} h a^{-1}$, Tithonia $50 \mathrm{~kg} \mathrm{~N} \mathrm{ha}^{-1}+$ Urea $50 \mathrm{~kg} \mathrm{~N} \mathrm{ha}^{-1}$, and VC $50 \mathrm{~kg} \mathrm{~N} \mathrm{ha}^{-1}$, and VC 100 $\mathrm{kg} \mathrm{N} \mathrm{ha}^{-1}$ for aluminum, phosphorus and calcium, respectively. On the other hand, lowest response was reported on treatment Tithonia $50 \mathrm{~kg} \mathrm{~N}^{-1}$, control and Tithonia $50 \mathrm{~kg} \mathrm{~N}$ ha $^{-1}+$ Urea $50 \mathrm{~kg} \mathrm{~N}^{-1}$ for aluminum, phosphorus and calcium, respectively. The treatments significantly influenced the percentage of polyphenols, vitamin $\mathrm{C}$ and the antioxidant capacity of Swiss chard while no significance was reported for total soluble solutes. The polyphenols and Vitamin C content were highest on Tithonia $100 \mathrm{~kg} \mathrm{~N} \mathrm{ha}^{-1}$ and control respectively. However, the control and Tithonia $100 \mathrm{~kg} \mathrm{~N} \mathrm{ha}^{-1}$ were not significantly different for both phytochemical. Low polyphenol and Vitamin C contents were recorded on VC $50 \mathrm{~kg} \mathrm{~N} \mathrm{ha}^{-1}$ and VC $100 \mathrm{~kg} \mathrm{~N} \mathrm{ha}^{-1}$, respectively. A similar trend was observed for antioxidant activity since a positive correlation was observed between the polyphenols and vitamin $\mathrm{C}$ and the antioxidant activity. The results demonstrate that there is potential for the use of Tithonia as an organic source of $\mathrm{N}$ to grow good quality Swiss chard rich in health promoting phytochemicals.

\section{Acknowledgements}

This research was funded by the University of Kabianga. Thanks to the Kenya Agricultural and Livestock Research Organization (KALRO)-Tea Research Institute for hosting all the laboratory analyses.

\section{References}

Adhikary, S. (2012). Vermicompost, the story of organic gold: A Review. Agricultural sciences, 3(7), 905-917. https://doi.org/10.4236/as.2012.37110

Aira, M., Monroy, F., \& Dominguez, J. (2009). Changes in bacterial numbers and microbial activity of pig slurry during gut transit of epigeic and anecic earthworms. Journal of Hazardous materials, 162, 1404-1407. https://doi.org/10.1016/j.jhazmat.2008.06.031

Alderfasi, A. A., Moftah, A. E., \& Aljuaed, A. M. (2010). Prospective study of using bio-organic farming system on growth, nitrate, oxalate and ascorbic acid contents in spinach. World Appl. Sci. J., 9(1), 49-54.

Arancon, N., \& Edwards, C. A. (2004). The use of vermicomposts as soil amendments for production of field crops. In C. A. Edwards, N. Q. Arancon, \& R. L. Sherman (Eds.), Vermiculture Technology: Earthworms, Organic Wastes and Environmental Management (pp. 129-148). CRC Press. https://doi.org/10.1201/b10453-11

Arancon, N. Q., Edwards, C. A., Bierman, P., Welch, C., \& Metzger, J. D. (2004). Influences of vermicomposts on field strawberries.1: Effects on growth and yields. Bioresour. Technol., 93, 145-153. https://doi.org/10.1016/j.biortech.2003.10.014

Argyropoulou, K., Salahas, G., Hela, D., \& Papasavvas, A. (2015). Impact of nitrogen deficiency on biomass production, morphological and biochemical characteristics of sweet basil (Ocimum basilicum L.) plants, cultivated aeroponically. Agriculture and Food, 3, 32-42.

Arroyo, C., Rojas, B. A., \& Rosales, R. (2003). Urea o Pollinaza como suplemento proteico para toretes consumiendo ensilage de pulpa de pejibaye. Agronomia Castarricense, 27(2), 69-73.

Bimova, P., \& Pokluda, R. (2009). Impact of organic fertilizers on total antioxidant capacity in head cabbage. Hort. Science (PRAGUE), 36(1), 21-25. https://doi.org/10.17221/9/2008-HORTSCI

Capulin, G. J., Nunez, E. R., Etchevers, B. J., \& Baca, G. A. (2001). Evaluacion del extracto liquid de estievcol bovino como insumo de nutricion vegetal en hidroponia. Agrociencia, 35, 287-299.

Castellanos, J. Z., Uvalle-Bueno, J. X., \& Aguilar-Santelises, A. (2000). Manual de interpretacion de analis de suelos, aguas agricolas, Planta ECP. 2 ed. INIFAP, Chapingo, Mexico.

Citak, S., \& Sonmez, S. (2009). Mineral contents of organically and conventionally grown spinach (Spinacea oleracea L.) during two successive seasons. J. Agric. Food Chem., 57, 7892-7898. 
https://doi.org/10.1021/jf900660k

Citak, S., \& Sonmez, S. (2010). Effects of conventional and organic fertilization on spinach (Spinacea oleracea L.) growth, yield, Vitamin $\mathrm{C}$ and nitrate concentration during two successive seasons. Scientia Horticulturae, 126, 415-420. https://doi.org/10.1016/j.scienta.2010.08.010

Coria-Cayupan, Y. S., De Pinto, M. I. S., \& Nazareno, M. A. (2009). Variations in bioactive substance contents and crop yields of lettuce (Lactuca sativa L.) cultivated in soils with different fertilization treatments. Journal of Agricultural and Food Chemistry, 57, 10122-10129. https://doi.org/10.1021/jf903019d

Dominguez, J. J., \& Edwards, C. A. (2011). Biology and ecology of earthworms epecies used for vermicomposting. In C. A. Edwards, N. Q. Arancon, \& R. L. Sherman (Eds.), Vermiculture Technology (pp. 27-40). Earthworms, Organic Waste and Environmental Management CRC Press, Boca Raton. https://doi.org/10.1201/b10453-4

Dzida, K., Jarosz, Z., \& Michalojc, Z. (2012). Effects of nitrogen fertilization on the yield and nutritive value of Beta vulgaris L. Journal of Elementology, 17, 19-29. https://doi.org/10.5601/jelem.2012.17.1.02

Edwards, C. A., \& Burrows, I. (1988). The potential of earthworm composts as plant growth media. In C. A. Edward, \& J. Neuhauser (Eds.), Earthworms in Environmental and Waste Management. SPB Academic publications. The Netherlands.

Elia, A., Santamaria, P., \& Serio, F. (1998). Nitrogen nutrition, yield and quality of spinach. J. Sci. Food Agric., 76, 341-346. https://doi.org/10.1002/(SICI)1097-0010(199803)76:3<341::AID-JSFA938>3.0.CO;2-4

Fairman, G. (2011). How to plant and care for your spinach.

Fatondji, D., Pasternak, D., \& Woltering, L. (2008). Watermelon production on stored rainwater in Sahelian sandy soils. Africa. Afr. J. Plant Sci., 2(12), 151-160.

Haimi, J., \& Huhta, V. (1990). Effect of earthworms on decomposition process in raw humus forest soil: A Microcosm Study. Biol. Fertil. Soils, 10, 78-183.

Hashmi, M. H. (1973). Spectrophotometric determination with potassium ferricyanide. In: Assay of Vitamins in Pharmaceutical Preparations. John Wiley and Sons. London, UK.

Hassan, S. A., Mijin, S., Yusoff, U. K., Ding, P., \& Wahab, P. E. M. (2012). Nitrate, ascorbic acid, mineral and antioxidant activities of Cosmos caudatus in response to organic and mineral-based fertilizer rates. Molecules, 17, 7843-7853. https://doi.org/10.3390/molecules17077843

Hernandez, A., Castillo, H., Ojeda, D., Arras, A., Lopez, J., \& Sanchez, E. (2010). Effect of vermicompost and compost on lettuce production. Chilean J. Agric. Res., 70(40), 585-589. https://doi.org/10.4067/S0718-58392010000400008

Hillstrom, R. J., Yacapin-Ammons, A. K., \& Lynch, M. S. (2003). Vitamin C inhibits lipid oxidation in human HDL I. Journal of Nutrition, 133, 3047-3051. https://doi.org/10.1093/jn/133.10.3047

Humphries, E. C. (1956). Mineral components and ash analysis. Modern Methods of Plant Analysis. Springer-Verlag, Berlin. pp. 468-502. https://doi.org/10.1007/978-3-642-80530-1_17

Ibrahim, M. H., Jaafar, H. Z., Rahmat, A., \& Rahman, Z. A. (2011). Effects of nitrogen fertilization, synthesis of primary and secondary metabolites in three varieties of Kacip Faimah (Labisia pumila Blume). International Journal of molecular sciences, 12, 5238-5254. https://doi.org/10.3390/ijms12085238

Ikemoto, Y., Teraguchi, M., \& Kogayashi, Y. (2002). Plasma level of nitrate in Congenital Heart Disease: Comparison with healthy children. Pediatr. Cardiol., 23, 132-136.

https://doi.org/10.1007/s00246-001-0036-9

Ishiwata, H., Yamada, T. Yoshiike, N., Nishijima, M., Kawamoto, A., \& Uyama, Y. (2002). Daily intake of food additives in Japan in five age groups estimated by the market basket method. Eur. Food Res. Technol., 215, 367-374. https://doi.org/10.1007/s00217-002-0577-z

Ivanovic, L., Milasevic, I., Topalovic, A., Djurovic, D., Mugosa, B., Knezevic, M., \& Vrvic, M. (2018). Nutritional and phytochemical content of Swiss chard from Montenegro, under different ertilization and irrigation treatments. British Food Journal. https://doi.org/10.1108/BFJ-03-2018-0142

Jaetzold, R., \& Schmidt, H. (1982). Farm Management Handbook of Kenya, Vol II. Ministry of Agriculture, Nairobi.

Jama, B., Buresh, C. A., Niang, R. J, Gachengo, A., Nzinguheba, C., \& Amadalo, B. (2000). Tithonia diversifolia 
as a green manure for soil fertility improvement in Western Kenya: A Review. Agroforestry System, 49, 201-221. https://doi.org/10.1023/A:1006339025728

Jama, B., Palm, C. A., \& Buresh, R. J. (1999). Using tithonia and fertilizers on maize in Western Kenya. Maseno Agroforestry Research Centre Newsletter, ICRAF, Nairobi, Kenya. Miti ni Maendeleo., 6, 3-4.

Jiraungkoorskul, W., \& Sahaphong, S. (2007). Efficacy of ascorbic acid reducing waterborne copper toxicity in Butterfish (Poronotus triacanthus). Journal of biological sciences, 7(4), 620-625. https://doi.org/10.3923/jbs.2007.620.625

Karori, S., Wachira, F., Wanyoko, J., \& Ngure, R. (2007). Antioxidant capacity of different types of tea products. African Journal of Biotechnology, 6, 2287-2296. https://doi.org/10.5897/AJB2007.000-2358

Khwairakpam, M., \& Bhargara, R. (2009). Vermitechnology for sewage sludge recycling. Journal of Hazardous Materials, 161, 948-954. https://doi.org/10.1016/j.jhazmat.2008.04.088

Koh, E., Charoenprasert, S., \& Mitchell, A. E. (2012). Effect of organic and conventional cropping systems on ascorbic acid, Vitamin C, flavonoids, nitrate, and oxalate in 27 varieties of spinach (Spinacia oleracea L.). $J$ Agric Food Chem., 60(12), 3144-3150. https://doi.org/10.1021/jf300051f

Kretschmer, M. (1999). Rote Rube Und Mangold (Beta vulgaris L.). Gemuse, 8, 507.

Leskovar, D. I., \& Paccini, G. (2005). Yield and leaf quality of processing spinach under deficit irrigation. Hort Science, 40(6), 1868-1870. https://doi.org/10.21273/HORTSCI.40.6.1868

Lesser, C., \& Treutter, D. (2005). Effects of nitrogen supply on growth, contents of phenolic compounds and pathogen (Scab) resistance of apple trees. Physiology and Plant, 123, 49-56. https://doi.org/10.1111/j.1399-3054.2004.00427.x

Lujan-Hidalgo, M. C., Perz-Gomez, L. E., Abud-Archila, M., Meza-Gordillo, R., Ruiz-Valdiviezo, V. M., Dendooven, L., \& Gutierrez-Miceli, F. A. (2015). Growth, phenolic content and antioxidant activity in Chincuya (Annona purpurea Moc \& Sesse ex Dunal) cultivated with vermicompost and phosphate rock. Compost Science \& Utilization, 940, 278-283. https://doi.org/10.1080/1065657X.2015.1046617

Masarirambi, M. T., Mbokazi, B. M., Wahome, P. K., \& Oseni, T. O. (2012). Effects of Kraal manure, chicken manure and inorganic fertilizer on growth and yield of lettuce (Lactica sativa L. var. Commander) in a semi-arid environment. Asian Journal of agricultural Sciences, 4(1), 58-64.

Massri, M., \& Labban, L. (2014). Comparison of different types of fertilizers on growth, yield and quality properties of watermelon (Citrillus lanatus). Agric. Sci., 5(6), 475-482. https://doi.org/10.4236/as.2014.56048

Miceli, A., \& Miceli, C. (2014). Effect of nitrogen fertilization on the quality of Swiss chard at harvest and during storage as minimally processed produce. Journal of food quality, 37, 125-134. https://doi.org/10.1111/jfq.12073

Mitic, V., Jovanovic, V. S., Dimitrijevic, M., Cvetkovic, J., \& Stojanovic, G. (2013). Effect of food preparation technique on antioxidant activity and plant pigment content in some vegetable species. Journal of Food and Nutrition Research, 1(6), 121-127.

Mozafar, A. (1993). Nitrogen fertilizers and the amount of Vitamins in plants: A Review. Journal of Plant Nutrition, 16, 2479-2506. https://doi.org/10.1080/01904169309364698

Munene, R., Changamu, E., Korir, N., \& Gweyi-Onyango, J. (2017). Effects of different nitrogen forms on rowth, phenolics, flavonoids and antioxidant activity in maranth species. Tropical Plant Research, 4(1), 81-89. https://doi.org/10.22271/tpr.2017.v4.i1.012

Munson, R. D. (1998). Principles of plant analysis. In Y. P. Kalva (Ed.), Handbook of Reference methods for plant analysis (pp. 1-24). CRC Press, Boca Raton, FL. https://doi.org/10.1201/9781420049398.ch1

Muramoto, J. (1999). Comparison of nitrate content in leafy vegetables from organic and conventional farms in California Centre for Agroecology and Sustainable food systems. University of California, Santa Cruz.

Nishikimi, M., Fukuyama, R. Minoshima, S., Shimizu, N., \& Yagi, K. (1994). Cloning and chromosomal mapping of the human nonfunctional gene for L-gulone-gamma-lactone Oxidase, the Enzyme for L-ascorbic acid biosynthesis missing in man. J. Biol. Chem., 269, 13685-13688.

Nziguheba, G., Paim, C. A., Buresha, R. J., \& Smithson, P. C. (1998). Soil phosphorus fractions and adsorption as affected by organic and inorganic sources. Plant Soil., 198, 159-168. 
https://doi.org/10.1023/A:1004389704235

Ogembo, J. O. (2015). Effects of phosphorus deficiency on secondary metabolites and distribution of African Nightshade in Siaya and Kisii Counties, Kenya. (Unpublished Master's Thesis). Kenyatta University, Nairobi, Kenya.

Okello, O. P. (2015). Effects of water stress on antioxidant activity and phenolic contents of African Nightshade in Siaya and Kisii Counties, Kenya. (Unpublished Master's Thesis). Kenyatta University, Nairobi, Kenya.

Palm, C. A., Gachengo, C. N., Delve, C. N., Cadisch, G., \& Giller, K. E. (2001). Organic inputs for soil fertility management in tropical Agroecosystems: Application of an organic resource database. Agriculture Ecosystems and Environment, 83, 27-42. https://doi.org/10.1016/S0167-8809(00)00267-X

Panche, A. N., Diwan, A. D., \& Chandra, S. R. (2016). Flavones: An Overview. J. Nutr. Sci., 5, 47. https://doi.org/10.1017/jns.2016.41

Pant, A. P., Radovich, T. J. K., Hue, V. N., Talcott, S. T., \& Krenek, A. K. (2009). Vermicompost extracts influence growth, minerals nutrients, phytonutrients and antioxidant activity in Pak Choi (Brassica rapa cv Bonsai, Chinesis group) grown under vermicompost and chemical fertilizer. J.S.C. Food Agric., 89, 2383-2392. https://doi.org/10.1002/jsfa.3732

Platt, B. S. (1962). Table of representative values of food commonly used in tropical countries. Medical Research Council, Spec. Rep. Series No. 302, HMSO, London.

Rajasree, G., \& Pillai, G. R. (2012). Effect of nitrogen on fruit quality and shelf life of cucurbitaceous vegetable bitter gourd. J. Plant nutrion. 35(8), 1139-1153. https://doi.org/10.1080/01904167.2012.676127

Russel, F. (1995). MSTAT C Computer Based Statistical Software Package.

Salahas, G., Papasavvas, A., Giannakopoulos, E., Tselios, T., \& Savvas, D. (2011). Impact of nitrogen deficiency on biomass production, gas exchange and betacyanin and total phenol concentrations in red beet (Beta vulgaris L.) plants. European Journal of Horticultural Science, 76(5), 194-200.

Santamaria, P. (2006). Nitrate in vegetables: Toxicity, content, intake and EC regulation. Journal of the Science of Food and Agriculture, 86, 10-17. https://doi.org/10.1002/jsfa.2351

Santamaria, A. P., Elia, A., Serio, F., \& Todaro, E. (1999). A Survey of nitrate and oxalate content in retail fresh vegetables. J. Sci. Food Agric., 79, 1882-1888. https://doi.org/10.1002/(SICI)1097-0010(199910)79:13<1882::AID-JSFA450>3.0.CO;2-D

Scheible, W. R., Morcuende, R., Czechowskr, T., Fritz, C., Osunner, D., Palacios-Rodjers, N., ... Stiff, M. (2004). Genome-wide reprograming of primary and secondary metabolism, protein synthesis, cellular growth processes and the regulating infrastructure of Arabidopsis in response to nitrogen. Plant Physiology, 136, 2483-2489. https://doi.org/10.1104/pp.104.047019

Sikora, L. J., \& Szmidt, R. A. K. (2005). Los compost como fuentes de nitrogeno, aportacion a la mineralizacion. Aportacion y Ventajas para la Nutricion Nitrogenada de las Plantas. pp. 287-292.

Singh, B. K., Pathak, K. A., Verma, A. K., Verma, V. K., \& Deka, B. C. (2011). Effects of vermicompost, fertilizer and mulch on plant growth, nodulation and yield of french bean (Phaseolus vulgaris L.). Vegetable Crops Research Bulletin, 74(1), 153-165. https://doi.org/10.2478/v10032-011-0013-7

Smatanova, M., Richter, R., \& Hlusek, J. (2004). Spinach and pepper response to nitrogen and sulphur fertilization. Plant Soil Environment, 50(7), 303-308. https://doi.org/10.17221/4036-PSE

Soobrattee, M. A., Neergheen, V. S., \& Luximon-Rammaa, A. (2005). Phenolics as potential antioxidant therapeutic agents: Mechanism and Actions. Mutation Research, 579, 200-213. https://doi.org/10.1016/j.mrfmmm.2005.03.023

Stefanelli, D., Goodwin, I., \& Jones, R. (2010). Minimal nitrogen and water use in horticulture: Effects on quality and content of selected nutrients. Food Res. Int., 43, 1833-1843. https://doi.org/10.1016/j.foodres.2010.04.022

Vazquez, T. J. A. C., Hernandez, M. F., Escareno, H. I. T., Vazquez, C. V., Robles, M. A. G., \& Hernandez, J. L. G. (2018). Chemical and rganic fertilization in the production of watermelon in Northern Mexico. Revista Mexicana de Ciencias Agricolas., 20, 4263-4275.

Velioglu, Y. S., Mazza, G., Gao, L., \& Oomah, B. D. (1998). Antioxidant activity and total phenolics in selected fruits, vegetables and grain products. Journal of Agricultural and Food Chemistry, 46, 4113. 
https://doi.org/10.1021/jf9801973

Welch, R. M. (2016). Micronutrients, agriculture and nutrition: Linkages for improved health and well being. Plant, Soil and Nutrition Laboratory, USDAARS, US.

Yildirim, A., Mavi, A., \& Kara, A. A. (2001). Determination of antioxidant and antimicrobial activities of Rumex crispus L. extracts. J. Agric. Food Chem., 49, 4083-4089. https://doi.org/10.1021/jf0103572

Yusof, Z., Ramasamy, S., Mahmoud, N. Z., \& Yaacob, J. S. (2018). Vermicompost supplementation improves the stability of bioactive anthocyanin and phenolic compounds in Clinacanthus nutans Lindau. Molecules, 23(6), 1345-1358. https://doi.org/10.3390/molecules23061345

Zarei, H. (1995). Investigation of nitrate accumulation in vegetables lettuce and spinach in relation to nitrogen fertilizers. (Unpublished MSc. Thesis). Tarbial Modarres University, Tehran, Iran.

\section{Copyrights}

Copyright for this article is retained by the author(s), with first publication rights granted to the journal.

This is an open-access article distributed under the terms and conditions of the Creative Commons Attribution license (http://creativecommons.org/licenses/by/3.0/). 